At the time of her death the Register and Leader gave editorially the following just estimate of her: "Mrs. Foster was an interesting and forceful woman and tremendously in earnest upon the temperance question. In her day, Iowans were either her loyal friends or her bitter enemies, because she was on the firing line of a bitter struggle. She came in for much unkind criticism because she was a new woman in old-fashioned times. but posterity must be kinder to her than her own generation, because she deserves it."

\title{
EDITOR HAS TOO MANY CALLERS
}

We have of late found it almost impossible to get sufficient time by ourselves to write a respectable portion of editorial. Our friends have recently taken such a wonderful liking to us, that they appear determined that we shall never feel sorrow because of solitude. This is certainly very kind in them, but it is not exactly justice to our subscribers, nor to ourselves, to take from us that time which should be devoted to the duties of our station. We are at all suitable times very glad to see our friends, but in candor we must say that there is a proper time for everything, and we should think, not exactly in place to visit an editor when he is engaged in his editorial duties.Warsaw Signal. In Bloomington [now Muscatine, Ia.] Herald, Feb. 11, 1842. In the Newspaper Division of the Historical, Memorial and Art Department of Iowa. 
Copyright of Annals of Iowa is the property of State of Iowa, by \& through the State Historical Society of Iowa and its content may not be copied or emailed to multiple sites or posted to a listserv without the copyright holder's express written permission. However, users may print, download, or email articles for individual use. 